\title{
STUDY OF ANTIBACTERIAL ACTIVITY OF THE PREPARATIONS WITH DIOXIDINE AND LEVOFLOXACIN ON MAIN PURULENT-INFLAMMATORY PROCESSES PATHOGENS
}

DOI: 10.36740/WLek202109115

\author{
Evheniia A. Shtaniuk, Oleksandra 0. Vovk, Larisa V. Krasnikova, Yuliia I. Polyvianna, Tetiana I. Kovalenko \\ KHARKIV NATIONAL MEDICAL UNIVERSITY, KHARKIV, UKRAINE
}

\begin{abstract}
The aim: Study of antibacterial activity of the preparations, containing antiseptic dioxidine and antibiotic levofloxacin in vitro on standard strains of main optional-anaerobic pathogens of purulent-inflammatory processes of surgical wounds S. aureus, E. coli, P. aeruginosa and definition of more effective ones on them.

Materials and methods: Solutions of dioxidine $1.2 \%$, dioxidine $1.2 \%$ with decamethaxin, Dioxisole, water soluble ointment with dioxidine $1.2 \%$ and levofloxacin $0.1 \%$ with decamethaxin were used in experiment. Antibacterial activity was studied on standard strains of S. aureus ATCC 25923, E. coli ATCC 25922, P. aeruginosa ATCC 27853. Distinguishing and identification of pure cultures of bacteria was done according to generally accepted microbiological methods. Determination of purulent-inflammatory processes pathogens sensitivity was done by disco-diffuse method on Mueller-Hinton medium. Antibacterial activity of solutions and ointments was studied with the help of agar diffusion method ("well" method) according to methodic recommendations. Each investigation was repeated 6 times. Method of variation statistics was used for the research results analysis. Results: All antibacterial preparations under study are effective and highly effective on S. aureus ATCC 25923, E. coli ATCC 25922, P. aeruginosa ATCC 27853. Solution with $1.2 \%$ dioxidine with decamethaxin and ointment with $0.1 \%$ levofloxacin and decamethaxin have larger growth retardation zones towards $S$. aureus and $P$. aeruginosa. E. coli strains are more sensitive to the solution of Dioxisole and ointment with $1.2 \%$ dioxidine.

Conclusions: All strains are sensitive, most of them are highly sensitive, up to 5 antibacterial preparations under study in vitro.
\end{abstract}

KEY WORDS: dioxidine, levofloxacin, S. aureus, E. coli,P. aeruginosa

Wiad Lek. 2021;74(9 p.l):2109-2111

\section{INTRODUCTION}

Topic of nosocomial infection, particularly in surgical practice, is valid in medicine all over the world [1-3]. Nosocomial purulent-inflammatory complication is always accompanied by pathogen, degree of infection severity course, character of lesions, spreading rate, treatment efficiency, etc. depend on the type of pathogen [4-6].

Growth of antibiotic-resistant strains of gram-negative and gram-positive flora reflecting general trend of microorganisms evolution is the consequence of irrational use of antibacterial preparations, causing certain difficulties in treatment and adversely affecting clinical results. Thus the study of the spectrum of purulent-inflammatory processes pathogens, their sensitivity to antibacterial preparations and regular microbiological monitoring implementation are very important [6].

Knowledge of soft tissues anatomy and level of infection localization play an important role in the choice of adequate treatment tactics [7]. Concrete clinical situation must be analyzed accounting risk factors and epidemiologic situation must be studied, which allows with a fairly high probability frequency defining potential pathogen and prescribing adequate rational empiric antibacterial therapy.

\section{THE AIM}

Search of most effective experimental antibacterial preparations on main optional-anaerobic pathogens of nosocomial purulent-inflammatory surgical wounds.

The aim was to study antibacterial activity of preparations containing antiseptic dioxidine and antibiotic levofloxacin on standard strains of surgical wounds pathogens $S$. aureus, E. coli, P. aeruginosa and find more effective ones on them.

\section{MATERIALS AND METHODS}

We used two solutions with dioxidine for experiment, namely: solution dioxidine $1.2 \%$, solution dioxidine $1.2 \%$ with decamethaxin, Dioxisole, two water soluble ointments of dioxidine $1.2 \%$ and levofloxacin $0.1 \%$ with decamethaxin.

Antibacterial activity was studied on standard strains of S. aureus ATCC 25923, E. coli ATCC 25922, P. aeruginosa ATCC 27853, received from SI «I.I.Mechnikov Institute of microbiology and immunology of the NAMS of Ukraine».

Antibacterial activity of solutions and ointments was studied with the help of agar diffusion method ("well" method) according to methodic recommendations [8]. Each investigation was repeated 6 times. 
Table I. Antibacterial activity of the preparations in the way of solutions and ointments on standard strains of $S$. aureus, E. coli and $P$. aeruginosa

\begin{tabular}{|c|c|c|c|c|c|}
\hline \multirow[b]{2}{*}{ Bacteria strain test } & \multicolumn{5}{|c|}{ Growth retardation zones diameter, $\mathrm{mm}(\mathrm{M} \pm \mathrm{m})$ at $\mathrm{n}=6$} \\
\hline & Sol. D* & Sol. D+D** & Sol. Dioxisole & $\begin{array}{c}\text { Ointment } \\
1.2 \% \text { dioxidine }\end{array}$ & Ointment $L+D^{*}$ \\
\hline $\begin{array}{c}\text { S. aureus } \\
\text { ATCC } 25923\end{array}$ & $24.68 \pm 0.74$ & $27.07 \pm 0.58$ & $26.63 \pm 0.42$ & $24.42 \pm 0.38$ & $29.75 \pm 0.80$ \\
\hline $\begin{array}{c}\text { E. coli } \\
\text { ATCC } 25922\end{array}$ & $27.32 \pm 0.92$ & $29.72 \pm 0.88$ & $31.93 \pm 0.56$ & $31.58 \pm 0.48$ & $26.1 \pm 0.52$ \\
\hline $\begin{array}{l}\text { P. aeruginosa } \\
\text { ATCC } 27853\end{array}$ & $23.32 \pm 0.88$ & $34.22 \pm 0.50$ & $30.02 \pm 0.52$ & $30.02 \pm 0.71$ & $32.77 \pm 0.54$ \\
\hline
\end{tabular}

Note: Sol. $D^{*}-1.2 \%$ dioxidine; Sol. $D+D^{* *}-1.2 \%$ dioxidine + decamethaxin;

ointment $L+D^{*}-0.1 \%$ levofloxacin + decamethaxin.

Method of variation statistics was used for the research results analysis. Reliability of the received results were determined by Student criterion $($ at $\mathrm{p}<0.05)$ [9].

\section{RESULTS}

Antibacterial preparations results study in vitro on standard strains of purulent-inflammatory processes pathogens are given in the Table I.

We can conclude that all strains are sensitive; most of them are highly sensitive, up to 5 antibacterial preparations under study. Retardation zones are from 23.32 to $32.77 \mathrm{~mm}$.

Solution with $1.2 \%$ dioxidine has high growth retardation zones towards S. aureus and P. aeruginosa (24.68 and 23.32 $\mathrm{mm}$ ) and the largest growth retardation zone on standard strain of E. coli ATCC 25922 and comprises $27.32 \mathrm{~mm}$.

As for solutions of $1.2 \%$ dioxidine with decamethaxin and Dioxisole, they were effective on all standard strains (growth retardation zones were from 27.07 to 34.22 and from 26.63 to $31.93 \mathrm{~mm}$, consequently).

Experimental ointment with $1.2 \%$ dioxidine is highly effective on E. coli ATCC 25922, P. aeruginosa ATCC 27853 (31.58 and $30.02 \mathrm{~mm}$, consequently) and effective on $S$. aureus ATCC $25923(24.42 \mathrm{~mm})$. Ointment with $0.1 \%$ levofloxacin and decamethaxin has high growth retardation zones of all standard strains from 26.1 to $32.77 \mathrm{~mm}$.

\section{DISCUSSION}

We studied research results of other scientists. The bactericidal effect on staphylococci is exerted by whole dioxidin and dioxidin in a 1: 1 dilution. The zone of inhibition of the growth of microorganisms was more than $10 \mathrm{~mm}$.

Dioxidine in a dilution of 1: 5 showed a bacteriostatic effect. In this case, the zone of inhibition of the growth of microorganisms was up to $10 \mathrm{~mm}$. Also dioxidine in a dilution of 1: 1 and 1: 5 had a stable bactericidal effect on E. coli and $P$. aeuriginisa [10]. It is known from other scientific sources that dioxidine is active in therapeutic concentrations against absolutely the majority of the studied strains, including the hospital microorganisms that are polyvalent resistant to antibacterial drugs [11]. Ointments on a water-soluble basis, containing of levoflaxacin (Levomecol) or 5\% of dioxidine are effective for treatment of wounds in the first phase of the wound process.
It is recommended to use 5\% dioxidine ointment for treatment of wounds, which couses by gram-negative microflora, in particular, Pseudomonas aeruginosa, Also, this ointment is effective in relation to anaerobic microflora in combination with aerobic one. In the treatment of the second phase of the wound process at the stage of maturation of granulations, you can use a $1 \%$ solution of dioxidine and ointments on a water-soluble basis [12].

In our studies, all the studied drugs with dioxidine and levofloxacin showed bactericidal action in relation to all standard strains of $S$. aureus, E. coli and P. aeruginosa. E. coli was most sensitive on the solution of Dioxisole and ointment with $1.2 \%$ dioxidine. Solution with $1.2 \%$ dioxidine with decamethaxin and ointment with $0.1 \%$ levofloxacin and decamethaxin had the largest growth retardation zones on $S$. aureus and P. aeruginosa.

\section{CONCLUSIONS}

1. All antibacterial preparations under study are effective and highly effective on S. aureus ATCC 25923, E. coli ATCC 25922, P. aeruginosa ATCC 27853.

2. Solution with $1.2 \%$ dioxidine with decamethaxin and ointment with $0.1 \%$ levofloxacin and decamethaxin have the largest growth retardation zones on S. aureus ATCC 25923 (27.07 and $29.75 \mathrm{~mm}$ ) and P. aeruginosa ATCC 27853 (34.22 and $32.77 \mathrm{~mm}$ ).

3. E. coli ATCC 25922 is most sensitive in vitro on the solution of Dioxisole and ointment with $1.2 \%$ dioxidine (31.93 and $31.58 \mathrm{~mm}$, consequently).

\section{REFERENCES}

1. Koza N.M. Health care related infections. Epidemiology and prophylaxis. Perm medical journal. 2013; 2: 135-141. (in Russian).

2. Lopatin A.F., Khapiy H.H., Khapiy I.H. et al. Nosocomial infection in intensive care units. Journal Effective pharmacotherapy. Anesthesiology and resuscitation. 2010; 1: 42-51. (in Russian).

3. Oralova K.A., Kishkentayeva S.K., Atachanova K.Ch. Epidemiology peculiarities, problems and difficulties of nosocomial infections prophylaxis at the present stage of medicals science development. Kazakhstan clinical medicine. 2012; 2 (25): 30-36. (in Russian).

4. Terechova R.P., Paschalova Yu.S., Skladan G.E. et al. Restructuring of surgical infection pathogens in patients with diabetes depending on their treatment strategy. Wound and wound infection. Prof. B.M.Kosuchenko Journal. 2015; 3: 22-29. (in Russian). 
5. Formulary of drugs registered in Ukraine as of 23.04.2018. https:// medhub.info/31246dcb (in Ukrainian).

6. Yakimenko E.A., Tbileli V.V., Zakatova L.V. et al. Approaches to choosing starting antibacterial therapy. Journal Acute and urgent states in doctor's practice. 2018; 2-3(71-72): 12-18. (in Russian).

7. Omarova S.M., Mollayeva A.M., Alieva A.I. et al. Spectrum and antibioticresistance of pathogens of nosocomial infecting of surgical wounds and urinary system organs in surgical patients. Clinical laboratory diagnostics, 2015; 60 (5): 45-48. (in Russian).

8. Volyansky Yu.L., Gritsenko I.S, Hirobokov V.P. et al. Methodic recommendations on the study of specific activity of antimicrobial drugs. Kyiv, 2004, 21-22 p.

9. Glants S. Medico-biological statistics, Moscow: 1999: 360p.

10. Loskutov A.E., Degtyar A.V., Stepansky D.A. Comparative assessment of the antimicrobial activity of local antiseptics in revision hip arthroplasty. Clinical medicine. 2017; 17 (22): 25-32. (in Russian).

11. Kryukov A.I., Kunelskaya N.L., Gurov A.V. et al. Possibilities of antiseptic agents in the treatment of laryngeal and tonsillar pathology. Medical advice. 2016.6: 36-40. (in Russian).

12. Ivanusa C. Choice of topical preparations. Modern principles of treatment of purulent wounds, St. Petersburg: Onpi-Press; 2017, 20-24 p. (in Russian).

$0118 U 000930$ "Improvement of diagnostics and treatment methods of purulent-inflammatory diseases caused by opportunistic microorganisms».

\section{ORCID and contributionship:}

Evheniia A. Shtaniuk: 0000-0002-1077-2819 ${ }^{A, B}$

Oleksandra O. Vovk: 0000-0002-0649-3163 ${ }^{\mathrm{C}}$

Larisa V. Krasnikova: 0000-0001-6675-4495 ${ }^{D}$

Yuliia I. Polyvianna: 0000-0001-8092-8164 ${ }^{E}$

Tetiana I. Kovalenko: 0000-0002-5687-2583 ${ }^{F}$

\section{Conflict of interest:}

The Authors declare no conflict of interest.

\section{CORRESPONDING AUTHOR Evheniia A. Shtaniuk \\ Kharkiv National Medical University \\ 4 Nauki avenue, 61022 Kharkiv, Ukraine \\ tel: +380509473130 \\ e-mail:evshtanyuk@gmail.com}

Received: 17.09 .2020

Accepted: 02.08 .2021

\footnotetext{
A - Work concept and design, B - Data collection and analysis, C - Responsibility for statistical analysis,
} D-Writing the article, $\mathbf{E}$-Critical review, $\mathbf{F}$ - Final approval of the article 